\title{
Constriction of the Fetlock Annular Ligament: Relationship between Clinical and Histopathological Findings
}

\author{
F. Torre', Cinzia Benazzi and Rosemarie Potschka ${ }^{1}$ \\ ${ }^{1}$ Clinica Equina Bagnarola, Budrio, Bologna - Italy \\ 2 Dip. Sanità Pubblica Veterinaria e Patologia Animale, Università di Bologna
}

\begin{abstract}
Summary
Stenosis or constriction of the fetlock annular ligament (FAL) has been diagnosed in 92 limbs of 85 horses, which have been subsequently submitted to FAL desmotomy. A previous clinical examination, including radiographic and ultrasonographic imaging, as well as synovial fluid analysis when needed, allowed a new classification of the constriction based on clinical findings: Type 1 (primary stenosis of FAL usually associated with synovial effusion of the tendon sheath); Type $2 a$ (stenosis of the FAL secondary to tendinitis of the superficial or deep digital flexor tendon); Type $2 \mathrm{~b}$ (stenosis of the FAL following a previously healed tendinitis with secondary thickening of the synovial membrane of the tendon sheath and subcutaneous tissue); Type 3 (stenosis of the FAL secondary to septic tenosynovitis). Type 1 included 40 cases (42 limbs); Type 2a 21 cases (26 limbs); Type 2b 17 cases ( 17 limbs) and Type 37 cases (7 limbs).

In 29 cases a sample of the FAL was taken during surgery and submitted for histological examination. A further classification was made, based on histological findings, and samples were divided into 3 different groups. In group A the FAL, the synovial membrane and subcutaneous tissue appeared thickened, with irregular distribution of collagen fibres, increased number of desmocytes, lack of reticular fibres, and moderate angiogenesis. Most of the cases that were clinically classified as Type 1 , Type $2 a$ and Type $2 b$ were included in group A. Group B was characterised by similar findings, but by the additional presence of inflammatory cells like lymphocytes and granulocytes. A small number of cases clinically classified as Type 1 and Type 2a were included into group B. In group C, a marked infiltration of inflammatory cells (lymphocytes and neutrophils) and, in more recent cases, the presence of fibrin were the dominant feature. All cases classified in Group C were clinically assigned to Type 3 . The histologic examination supported the diagnosis of "desmitis“ in cases belonging to the groups B and $\mathrm{C}$, wheras cases included in group A showed only thickening of the FAL without signs of inflammation.
\end{abstract}

keywords: $\quad$ annular ligament, constriction, desmitis, fetlock, horse

\begin{abstract}
Striktur des Fesselbeinringbandes: Beziehung zwischen klinischen und histopathologischen Befunden
Eine Stenose oder Striktur des Fesselringbandes (RB) wurde in 92 Gliedmaßen von 85 Pferden diagnostiziert. Diese Pferde wurden anschließend einer Desmotomie des Ringbandes unterzogen. Eine vorausgehende klinische Untersuchung, die eine Röntgen- und Ultraschalluntersuchung und falls notwendig eine Prüfung der Synovialflüssigkeit mit einschloß, erlaubte eine neue Klassifizierung der Striktur, die auf klinischen Befunden beruht: Typ 1 (primäre Stenose des RB, gewöhnlich begleitet von vermehrter Synovialfüllung der Sehnenscheide); Typ $2 \mathrm{a}$ (Stenose des RB sekundär nach Tendinitis der oberflächlichen oder tiefen Beugesehne); Typ 2b (Stenose des RB nach zuvor ausgeheilter Tendinitis mit sekundärer Verdickung der Synovialmembran der Sehnenscheide und des Unterhautgewebes); Typ 3 (Stenose des RB sekundär nach septischer Tenosynovitis). Typ 1 umfasst 40 Fälle (42 Giedmaßen), Typ 2a 21 Fälle (26 Gliedmaßen), Typ 2b 17 Fälle (17 Gliedmaßen) und Typ 37 Fälle (7 Gliedmaßen).

In 29 Fällen wurde intraoperativ eine Probe des RB entnommen und zur histologischen Untersuchung eingesandt. Es wurde eine weitere Klassifizierung, basierend auf den histologischen Ergebnissen aufgestellt und die Proben wurden in 3 verschiedene Gruppen aufgeteilt. In Gruppe A waren das Ringband, die Synovialmembran und das Unterhautgewebe verdickt und wiesen eine unregelmässige Verteilung der Kollagenfasern auf, sowie eine erhöhte Anzahl von Desmozyten, einen Mangel an Retikularfasern und eine gemässigte Angiogenese. Gruppe A umfasste die meisten Fälle die klinisch als Typ 1, 2a und 2b klassifiziert worden waren. In Gruppe B waren die Befunde ähnlich, aber diese Gruppe wies zusätzlich Leukozyten wie Lymphozyten und Granulyzyten auf. Wenige Fälle, die klinisch als Typ 1 und 2a klassifiziert worden waren, wurden in Gruppe B eingeschlossen. Der wichtigste Befund in Gruppe C war eine ausgeprägte Infiltration von Lymphozyten und Neutophilen und - in frischen Fällen - das Vorhandensein von Fibrin. Alle Fälle, die der Gruppe C zugeschrieben wurden, fielen klinisch unter den Typ 3. Die histologische Untersuchung bestätigte die Diagnose Desmitis in den Fällen die zu Gruppe B und C gehörten, während die Fälle die der Gruppe A zugeteilt wurden nur eine Verdickung ohne Anzeichen einer Entzündung aufwiesen.
\end{abstract}

Schlüsselwörter: Fesselringband, Striktur, Desmitis, Pferd

\section{Introduction}

Stenosis or desmitis of the fetlock annular ligament $(F A L)$ is a well known clinical syndrome in horses (Adams, 1974; Adams, 1977; Fricker, 1982; Mcllwraith, 1987; Verschooten and Picavet, 1986; Dik, Van Den Belt and Keg, 1991; Dik, Dyson and Vail, 1995). Progress in diagnostic techniques has enabled better assessment of damage to the soft tissues in the distal metacarpal/metatarsal area. The following have been employed, jointly with clinical examination: radiology (Hago and Vaughan, 1986; Stanek and Edinger, 1990), ultrasonography (Spaulding, 1984; Genovese, Rantanen, Hauser et al., 1986; Stanek and Edinger, 1990; Dik, Van Den Belt and Keg, 1991; Genovese, Reef, 
Longo et al., 1996) or a combination of the two techniques (Redding, 1994) and more recently, tenovaginoscopy (Nixon, 1990; Edinger, 1996).

FAL constriction can be either primary or secondary. Primary FAL constriction occurs with a reduction in the fetlock canal internal diameter following thickening of the FAL, surrounding subcutaneous tissue, or a combination of both. Secondary or relative stenosis occurs when one or more of the canal structures increases in volume, i.e. the two digital flexor tendons and the synovial membrane of the tendon sheath, or an increase in synovial fluid, e.g. in the case of idiopathic or septic tenosynovitis occurs. The fact that the constriction is not constantly associated with FAL alterations spurred some authors to suggest the term fetlock tunnel syndrome instead of annular ligament stenosis Nan Den Berg, Rijkenhuizen, Németh et al., 1995). There are several possible causes of this syndrome: trauma, hyperextension of the fetlock at work, synovitis of the tendon sheath, or tendinitis of the superficial (Gerring and Webbon, 1984) or deep digital flexor tendons (Barr, Dyson, Barr et al., 1995).

Patterns are similar in primary and secondary stenosis, although ultrasonographic alterations in the structures within the fetlock canal are present in the latter. Synovial effusion is almost always present, lameness is moderate in non septic cases but marked in septic tenosynovitis (Baxter, 1987; Schneider, Bramlage, Moore et al., 1992; Stashak, Vail, Park et al., 1996). Although the causes may vary, the clinical aspects of the syndrome are characteristic. Restricted sliding of the flexor tendons in the fetlock canal causes long-term, persistent, mild to moderate lameness that improves little, if at all, with rest, and worsens on return to exercise or training (Dik, Dyson and Vail, 1995). Viewed from the side, there is usually a characteristic "notch" in the palmar/plantar outline of the fetlock. Diagnosis is made by clinical examination (Adams, 1974; Mcllwraith, 1987) embracing a flexion test, diagnostic local analgesia including intra-thecal analgesia of the digital tendon sheath, and ultrasonography.

Ultrasonography allows visualisation of pathology in the fetlock canal structures, in addition to measuring thickness of the FAL itself or the distance between the skin and the superficial flexor tendon (Dik, Van Den Belt and Keg, 1991; Barr, Dyson, Barr et al., 1995; Stashak, Vail, Park et al., 1996). Radiography, with or without contrast medium, can also demonstrate FAL constriction, tendon sheath distension, the palmar/plantar profile of proximal sesamoid bones Nerschooten and Picavet, 1986; Stanek and Edinger, 1990) and possible presence of bone metaplasia in the digital tendon sheath.

Histologically, FAL desmitis is typified by changes in collagen fibres, lymphocyte infiltration and increased vessel quantity Nerschooten and Picavet, 1986). Under normal conditions, FAL has well ordered collagen fibres with fibrocytes in the spaces between fibres and small diameter vessels (Stashak, Vail, Park et al., 1996). FAL is associated with the parietal layer of the tendon sheath synovial membrane, which covers it dorsally, and with subcutaneous tissue surrounding its palmar/plantar aspect. Subcutaneous variations occur under normal conditions as the subject ages, but this does not occur in the synovial layer (Van Den Berg, Rijkenhuizen, Németh et al., 1995).

In cases with tendon sheath distension, synovial fluid analysis will rule out sepsis (Baxter, 1987; Wright and Scott, 1989; Schneider, Bramlage and Moore, 1992; Bertone, 1995).

Surgical management entails annular ligament desmotomy and is the most widespread method of resolution (Adams, 1977; Gerring and Webbon, 1984; Torre, Dora Genocchi and Potschka, 1991; Barr, Dyson, Barr et al., 1995; Stashak, Vail, Park et al., 1996). The operation can be performed through tenoscopy (Nixon, Sams and Ducharme, 1993; Nixon, 1996), which enables inspection of the structures in the fetlock canal (Nixon, 1990; Edinger, 1996).

The purpose of this study is to classify different types of fetlock annular ligament stenosis, identified according to clinical characteristics, and to compare the resulting groups with a second classification, based on histological examinations of samples taken from the ligaments during surgery.

\section{Materials and Methods}

This study included 85 horses operated for desmotomy of the FAL at the Clinica Equina Bagnarola, Budrio, Bologna (Italy) over 11 years (1985-1996).

Age, sex, duration of the condition and previous treatments were recorded for each horse on arrival. Every subject was then examined with accurate palpation and flexion test. Diagnostic blocks, radiography, ultrasonography and synovial fluid examinations were carried out in different combinations as necessary. In 5 cases, the radiographic examination was performed using positive contrast medium (iopamidol) injected into the tendon sheath. Ultrasonography was carried out using a $5.5 \mathrm{MHz}$ linear probe (Echokamera SSD-210 DX II, Aloka Co. Ltd., Japan) or a 7.5 MHz linear probe (Aloka 500, Aloka Co. Ltd., Japan) and a stand-off was always employed in order to improve evaluation and measurement of the FAL. In cases of severe lameness, e.g. in suspected septic tenosynovitis, some stages were avoided (diagnostic blocks, flexion tests), in preference to others (synovial fluid analysis). When lesions in the superficial or deep digital flexor tendon were associated with FAL constriction, ultrasonography allowed a classification of lesions according to the literature (Genovese, Rantanen, Hauser et al., 1986).

Clinical patterns were split into four groups

Type 1 (40 horses; 42 limbs): primary stenosis of the FAL associated with a varying degree of effusion and thickening of the tendon sheath but not with other pathology. Ultrasonographically, the FAL and the surrounding subcutaneous tissue were thickened, and the amount of fluid in the tendon sheath often increased (Figure 1). In two cases there was radiographic evidence of bone metaplasia of the tendon sheath (Figure 2).

Type 2a (21 horses; 26 limbs): stenosis of the FAL associated with acute tendinitis of the superficial or deep digital flexor tendon (Figure 3). 
Type 2b (17 horses; 17 limbs): stenosis of the FAL following chronic tendinitis of the superficial digital flexor tendon. This type most resembles Type 1 as the stenosis inside the fetlock tunnel was not caused purely by increased thickness
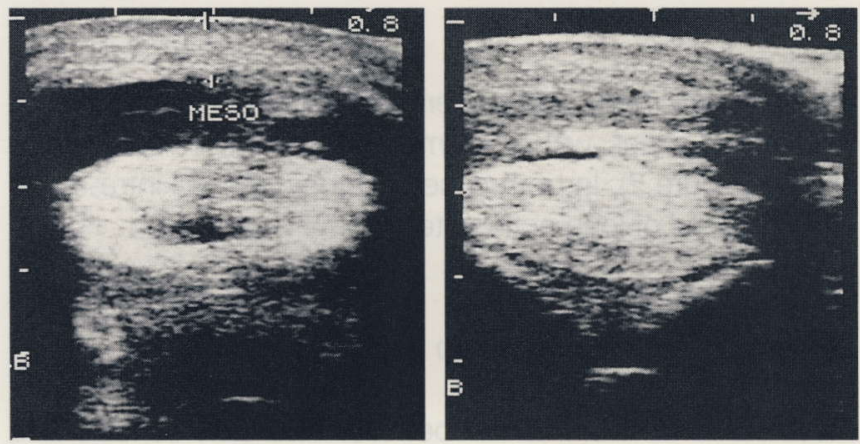

Fig. 1: Type 1

A: Synovial effusion of the digital tendon sheath associated with thickening of the FAL ;

B: A more distal view of the same case in which the synovial effusion is visible on the lateral aspect.

A: Synoviazunahme der Sehnenscheide einhergehend mit einer Verdickung des Fesselringbandes.

B: Distale Ansicht des gleichen Falles. Hier ist die Synoviazunahme lateral sichtbar.

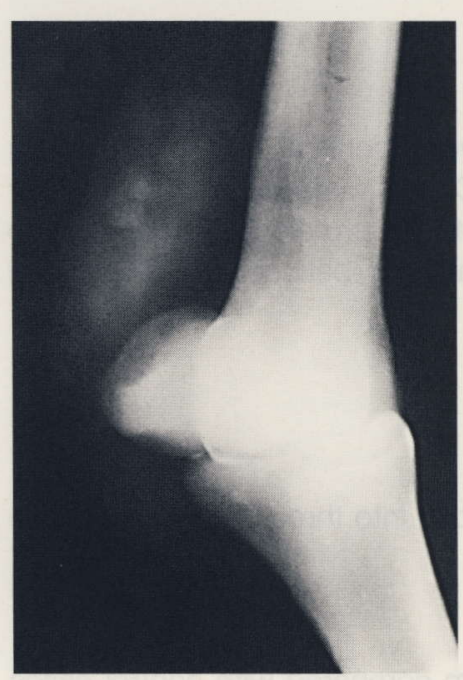

Fig. 2: Area of dystrophic mineralisation in the digital tendon sheath.

Bereich dystrophischer Mineralisation der Fesselbeugesehnenscheide. of the tendon structure, but also by a secondary thickening of the FAL-synovial membrane-subcutaneous tissue complex due to the chronic nature of the inflammatory process (Figure 4). Type 3 (7 horses; 7 limbs): stenosis of the FAL following septic tenosynovitis of the digital tendon sheath. Symptomatology was of acute onset and the synovial fluid examination revealed increased values of total protein (range 4.1-5.8 $\mathrm{g} / \mathrm{dl}$ ) and leukocytes (range 24,000-54,000/ $\mathrm{mm}^{3}$ ).

All cases were treated surgically by desmotomy of the FAL. Tenoscopy was not used. The patient was positioned under general anaesthesia in lateral recumbency with the affected limb placed upward. A $5 \mathrm{~cm}$ incision was effected about $1 \mathrm{~cm}$ palmarly and parallel to the common digital palmar vessels and nerves, starting from the FAL proximal margin. The FAL was cut along its entire length. Part of the incision was performed „blind“, i.e. without cutting the skin. Any adhesions present were removed and the synovial cavity was flushed with sterile saline solution before suturing. All horses were allowed to walk the day after the operation, and resumed normal work after 8 weeks. In 9 cases in which FAL stenosis was associated with tendinitis of the superficial digital flexor tendon, desmotomy of the FAL was performed on the medial side in association with desmotomy of the accessory ligament of the superficial digital flexor tendon following the technique previously described (Bramlage, 1986; Bramlage et al., 1988; Hogan and Bramlage, 1995). In the latter cases, post operative management included 10 days rest in the box, followed by $6-8$ weeks of hand walking.

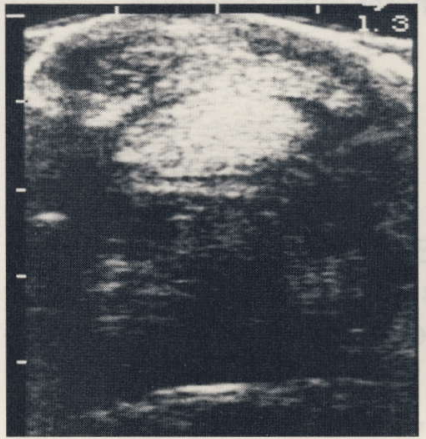

Fig. 3: An acute case of tendinitis of the superficial digital flexor tendon associated with secondary stenosis of the fetlock canal (Type 2a).

Akute Tendinitis der oberflächlichen Beugesehne, einhergehend mit sekundärer Stenose des Fesselringbandkanals.

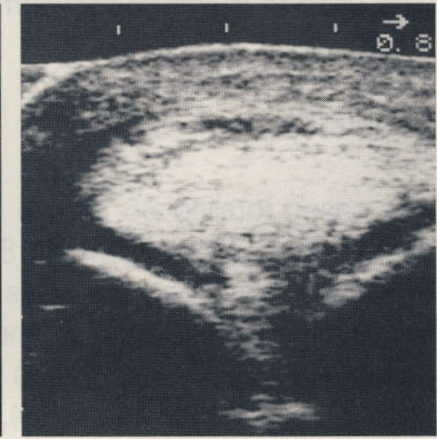

Fig. 4: The sonogram shows a chronic thickening of the synovial membrane of the digital tendon sheath and subcutaneous tissue (Type 2b).

Die sonographische Untersuchung zeigt eine chronische Verdickung der Synovialmembran der Sehnenscheide und des Unterhautgewebes.
In type 3 cases, in addition to desmotomy, the synovial cavity was surgically debrided and flushed with lactated Ringer's solution. An incision at the distal pouch of the tendon sheath in the pastern area ensured open drainage in the days immediately after the operation in each case.

During the operation, a FAL sample, dissected along its entire length, was taken from 29 horses. The sample was taken at the point of incision and the removed strip had a width of $4-8 \mathrm{~mm}$. The 29 horses included 24 Standard-

Tab. 1: Distribution of different Types of FAL constriction between limbs.

Verteilung der verschiedenen Typen der Fesselringbandstriktur auf die Gliedmassen.

\begin{tabular}{|l|c|c|c|c|c|c|}
\hline TYPE & $\begin{array}{c}\text { No. } \\
\text { Limbs }\end{array}$ & $\begin{array}{c}\text { No. } \\
\text { Horses }\end{array}$ & LF & RF & LH & RH \\
\hline Type 1 & 42 & 40 & 15 & 15 & 4 & 8 \\
\hline Type 2a & 26 & 21 & 16 & 8 & 1 & 1 \\
\hline Type 2b & 17 & 17 & 11 & 6 & 0 & 0 \\
\hline Type 3 & 7 & 7 & 1 & 2 & 2 & 2 \\
\hline TOTAL & 92 & 85 & 43 & 31 & 7 & 11 \\
\hline
\end{tabular}


breds, 3 Show Jumpers, 1 Quarter Horse and 1 Arabian. The samples were fixed in $10 \%$ buffered formalin solution and were then subjected to histological examination. The cross section of each sample included the actual annular ligament and a portion of subcutaneous tissue. The synovial layer was also present in 4 cases. The samples were cut in 5 micron sections and were stained with haematoxylin-eosin, Orcein for elastic fibres, and Gomori for reticular fibres. FAL thickness was measured with a gauge, and an image analyser (Cytometrica, BYK Gulden, Italy) with a x 25 lens was used to measure the diameter of the arterioles.

\section{Results}

The cases totalled 85 horses and 92 limbs. There were 59 entire males, 18 females and 8 geldings. Age ranged from 2 to 14 years (average 4.4). This average age was significantly higher when compared to the clinic's population (average age 3.7 years). Standardbreds were most numerous (70), followed by Show Jumpers (9), Thoroughbreds (3), Quarter Horses (2) and Arabians (1). The breed distribution (82.3\% Standardbreds) reflected the normal clinic's population, in which Standardbreds represent $83.4 \%$ of the total case load.

\section{Clinical examination}

On the basis of clinical findings, the cases were classified as follows (see Table 1):

Type 1

40 cases in 42 limbs ( 2 bilateral): 15 front left, 15 front right, 4 rear left, and 8 rear right. Tendon sheath effusion was frequent, although the degree of distension was not classified to any scale.

\section{Type 2a}

21 cases in 26 limbs (5 bilateral): 16 left forelimb, 8 right forelimb, and 1 both left hindlimb and right hindlimb in the only rear bilateral case. In these horses, constriction of the FAL was associated with tendinitis of the superficial digital flexor tendon. In one case, tendinitis affected the deep digital flexor tendon. Generally, tendinitis had preceded constriction of the $F A L$, although history did not always clearly indicate whether the alterations to the FAL were present prior to tendinitis.

\section{Type $2 b$}

17 cases in 17 limbs, 11 front left, and 6 front right.

\section{Type 3}

7 cases, 7 limbs: 1 front left, 2 front right, 2 rear left and 2 rear right. In this case, ultrasonography was not performed constantly since history and clinical evidence were sufficient for diagnosis. In 2 cases, sepsis had been caused by small penetrating wounds in the digital sheath area, in 3 cases by large wounds, whereas in another 2 cases iatrogenic complications followed intra-thecal injection of steroids. In 2 cases, in addition to the distension of the digital tendon sheath, ultrasonography revealed fibrin masses organised to a varying degree.

\section{Radiographic examination}

In two cases there was evidence of focal bone metaplasia, in rounded areas with a diameter of $2 \mathrm{~cm}$, in the tendon sheath (Figure 2). In both cases, history referred intra-synovial injections of long acting steroids.

\section{Ultrasonographic examination}

Measurements were taken between the skin surface and the FAL dorsal border, immediately palmar to the sesamoid apex (Dik, Van Den Belt and Keg, 1991; Stashak, Vail, Park et al., 1996). This thickness varied from 4 to $9 \mathrm{~mm}$, with an average thickness of $6.7 \mathrm{~mm}$. The thickness of the FAL as an isolated structure was reported in one normal horse only and was 1-2 mm (Dik, Van Den Belt and Keg, 1991). The average thickness in Type 3 cases was not recorded in the present study because ultrasonography was not considered a crucial diagnostic tool in these special cases.

\section{Synovial fluid examination}

The methods employed were identical to those used in cases of septic arthritis. Culture data were collected for one case only. The range of total protein values was 4.1 to $5.8 \mathrm{~g} / \mathrm{dl}$. Leukocytes ranged between 24,000 and $54,000 / \mathrm{mm}^{3}$.

\section{Histological examination}

The FAL samples were divided into three Groups based on histological examination:

\section{Group A (21 cases)}

FAL was thickened (> $1 \mathrm{~mm}$ compared with control cases in which the FAL thickness was less than $1 \mathrm{~mm}$ ). In 3 out of 4 samples the synovial membrane appeared thicker (Figure 5), composed of 10-12 layers of nuclei instead of the normal 1-2 layers. The elastic fibres were no longer normally arranged between the collagen fibres, but were split, and were thinner or absent in some areas. Collagen fibres were thicker and variable in size and orientation (Figure 6). There was increased number of desmocytes. Reticular fibres were present in vessel walls only. With the exception of two cases, typified by slight angiogenesis, arterioles appeared normal, with an average diameter of $0.07 \pm 0.02 \mathrm{~mm}$. No differences were observed between front and rear limbs.

\section{Group B (5 cases)}

FAL was thickened with mild inflammatory infiltrate consisting of lymphocytes and granulocytes. The characteristics were 


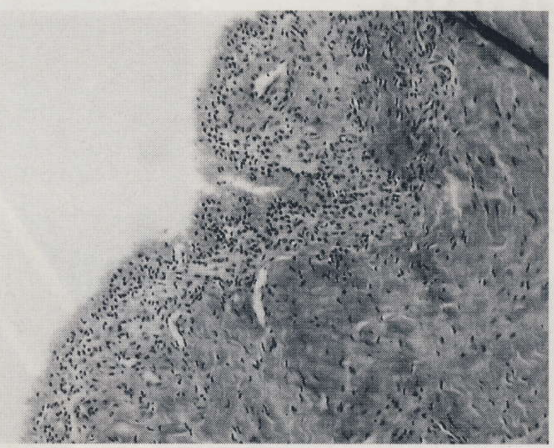

Fig. 5: Type 2b, Group A: thickening of Fig. the synovial membrane, composed of 10-12 layers of cells instead of the normal 1-2 layers $(\mathrm{H}-\mathrm{E} ; 10 \mathrm{x})$.

Typ 2b, Gruppe A: Verdickung der Synovialmembran, die aus 10-12 Zellagen besteht, statt der üblichen 1-2 Lagen.

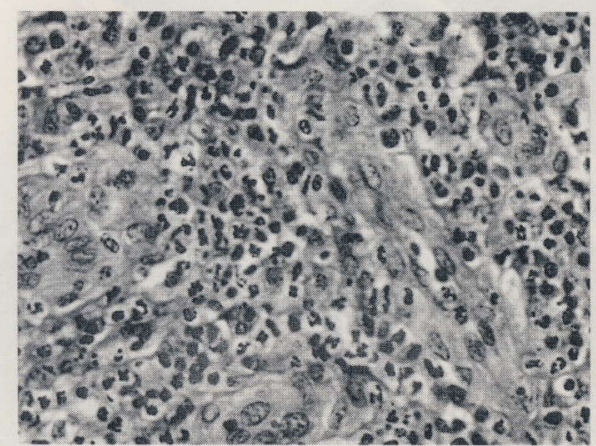

Fig. 7: Type 3, Group C: large infiltration of inflammatory cells between collagen bundles (H-E; $6.3 \mathrm{x})$.

Typ 3, Gruppe C: deutliche Einwanderung von Entzündungszellen zwischen kollagenen Faserbündeln.

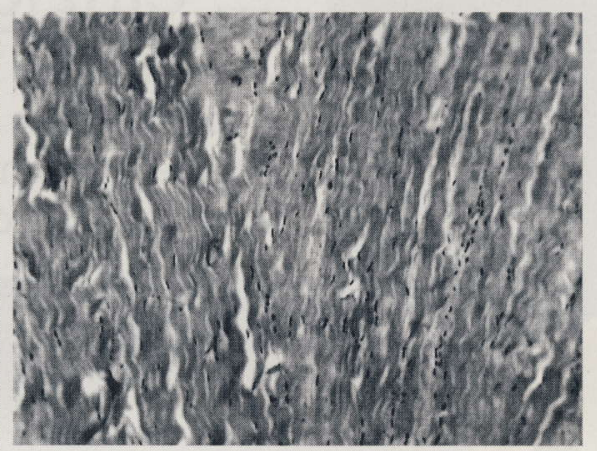

Fig. 6: Type 2a, Group A: the boundles of fibres composed by thicker fibrils preserve a parallel pattern $(\mathrm{H}-\mathrm{E}$; $10 x)$.

Typ 2a, Gruppe A: Die Faserbündel, die aus dickeren Fibrillen bestehen, bewahren die parallele Anordnung.

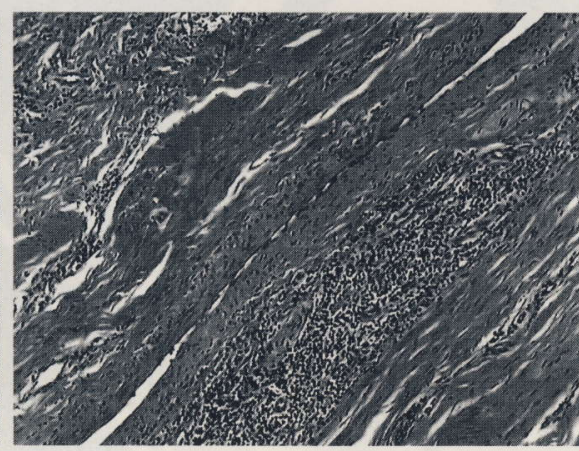

Fig. 8: Close up showing granulation tissue heavily infiltrated by neutrophylic granulocytes and lymphocytes (H-E; $25 x)$.

Die Nahaufnahme zeigt Granulationsgewebe, welches von neutrophilen Granulozyten und Lymphozyten infiltriert wird.

Group C (3 cases)

marked infiltration of inflammatory cells (lymphocytes and neutrophils) and/or fibrin. In the first case, there was a core consisting of neutrophils surrounded by lymphocytes and granulation tissue resembling an abscess. Lymphoid accumulation had also occurred around vessels. In the second case, the lesions had a greater degree of infiltration (Fig. 7) and were characterised by the presence of neutrophils and lymphocytes, a thick web of fibrin and granulation tissue, situated between the collagen fibre layers (Fig. 8). The third case was characterised by infiltration with neutrophils and fibrin only.

When clinical and histo-pathological findings were compared, it was noted that of the 10 Type 1 cases, 8 were in Group A and 2 in Group B, of the 10 Type 2a cases, histologically 7 belonged to Group A and 3 to group B, and the 6 Type $2 \mathrm{~b}$ cases all belonged to Group A. In contrast, all the Type 3 cases fell under Group C. These data are summarised in table 2.

\section{Discussion}

The classification of different clinical patterns of FAL constriction proposed here has some similarities with a classification reported by Stashak and colleagues (Stashak et al., 1996), which, however, did not distinguish the two different conditions in Type 2. This distinction seems appropriate since, aIthough they have a common origin,

similar to those observed in Group A but, in addition, inflammatory cells were present close to the vessels (lymphocytes in 4 cases; lymphocytes and neutrophils in one case).

Tab. 2: Distribution of cases following clinical and histological classification.

Verteilung der Fälle nach klinischer und histologischer Beurteilung.

\begin{tabular}{|l|c|c|c|c|}
\hline Type & No. Cases & Group A & Group B & Group C \\
\hline Type 1 & 10 & 8 & 2 & 0 \\
\hline Type 2a & 10 & 7 & 3 & 0 \\
\hline Type 2b & 6 & 6 & 0 & 0 \\
\hline Type 3 & 3 & 0 & 0 & 3 \\
\hline Total & 29 & 21 & 5 & 3 \\
\hline
\end{tabular}

Type $2 \mathrm{a}$ and Type $2 \mathrm{~b}$ cases differ especially as the former is a sub-acute condition and the latter a typically chronic pattern and thus, in some respects, similar to Type 1. In another previous classification of cases of FAL constriction, four categories were considered: Type 1, with thickening and distension of the digital sheath and thickening of the FAL, with normal digital flexor tendons; Type 2, with distention of the tendon sheath, without abnormalities on digital flexor tendons and FAL; Type 3, with thickening of FAL associated with loss of echogenicity of the superficial digital flexor tendon; Type 4, characterised by a thick layer of subcutaneous tissue around the palmar aspect of the digital sheath (Dik, Van Den Belt and Keg, 1991). The classification proposed in the present study differs from the latter since no cases described as Type 4 were encountered, whereas cases of FAL constriction associated with septic tenosynovitis (not reported by Dik and colleagues) were not infrequent. 
The thickness of the synovial membrane-annular ligamentsubcutaneous tissue complex typical of Type $2 \mathrm{~b}$, apparently cannot be merely ascribed to thickening of the synovial layer which, as previously reported (Van Den Berg, Rijkenhuizen, Németh et al., 1995) does not modify with age. However, thickening of the synovial layer has been observed in association with pathology of the palmar surface of the superficial digital flexor tendon, which, according to some authors, cannot be revealed ultrasonographically but only tenoscopically (Edinger, 1996).

These results differ in some ways with those reported by Stashak et al. (1996). Stashak and colleagues reported a lack of correlation between clinical and anatomo-pathological findings in Type 1 and Type 2 cases, whereas the present study suggests some correlation. Differences can be explained by the absence of sub-acute cases in Type 2 lesions reported by Stashak and colleagues. In Stashak et al's series, an average duration of 5 months was recorded for Type 1 lesions, 7 months for Type 2 and 2 months for Type 3. These durations, especially in regard to Type 2 and Type 3 cases, are well above those mentioned in the present study and lead to significant differences not only in prognosis but also in anatomo-pathological findings. In 7 months, a Type $2 \mathrm{a}$ lesion can progress to a $2 \mathrm{~b}$ lesion, resulting in thickening of FAL and subcutaneous tissue similar to that noted in Type 1 lesions.

Stashak and colleagues indicated the distance between skin and palmar/plantar border of the superficial digital flexor tendon as $3.6 \mathrm{~mm}$ in normal cases, and $9.1 \pm 2.3 \mathrm{~mm}$ in pathological cases. No modifications in thickness had been previously reported in cases characterised by synovial distension only, and thickness of 3 to $6 \mathrm{~mm}$ in cases affected by thickening of the digital sheath or tendon lesions (Dik, Van Den Belt and Keg, 1991).

However, in the present study, the thickness measured by the pathologist in 6 cases (5 from Group A and one from Group B) was approximately $1 \mathrm{~mm}$. As the difference between the Group A and B consisted in the presence or absence of a few inflammatory cells, there was no difference in thickness. Histologically, the normal ligament consisted of well ordered collagen fibres with fibrocytes in the interfibrillar spaces and small vessels. In the pathological cases, hypervascularity and mixed patterns of hypercellularity and fibroplasia were noted. The elastin filaments had diminished. Desmitis was present in 3 cases of Group C (subacute in the first two cases with granulation tissue and abscess-like lesions; acute in the third case) in association with septic tenosynovitis. The cells in the two cases characterised by granulation tissue and abscess-like lesions showed a more chronic process, whereas in the third case only neutrophils and fibrin were observed, without either lymphocytes or granulation tissue.

Stashak and colleagues concluded that the histological alterations were not prognostic. They also suggested that the inflammatory reaction and attempts to repair caused the observed modifications. Age and stress related to training and racing may play a concomitant role (Goodship and Birch, 1996). The ultrasonographic signs recorded in the present study justified the term desmitis of the FAL, whereas histological findings supported it in Groups B and C only. In the cases of Group A, one can only refer to non inflammatory thickening.

\section{References}

Adams O.R. (1974) Constriction of the palmar (volar) annular ligament of the fetlock in the horse. Vet.Med.Small Anim. Clin., 69, 327-329.

Adams O.R. (1977) Constriction of the palmar (volar) or plantar annular ligament of the fetlock in the horse. Proc. Am.Ass.Equine Pract., 212-217.

Barr A.R.S., Dyson S.J, Barr F.J. and O'Brien J.K. (1995) Tendonitis of the deep digital flexor tendon in the distal metacarpal/metatarsal region associated with tenosynovitis of the digital sheath in the horse. Equine vet. J., 27, 348-355.

Baxter G.M. (1987) Retrospective study of lower limb wounds involving tendons, tendon sheats or joints in horses. Proc. Am.Ass. Equine Pract., 715-728.

Bertone A.L (1995) Infectious tenosynovitis. Vet. Clin. of North Am., Equine Pract. 11, 163-176.

Bramlage L.R. (1986) Superior check ligament desmotomy as a treatment for superficial digital flexor tendonitis: initial report. Proc. Am. Ass. Equine Pract., 365-369.

Bramlage L.R., Rantanen N.W., Genovese R.L. and Page L.E. (1988) Long-term effects of surgical treatment of superficial digital flexor tendinitis by superior check ligament desmotomy. Proc. Am. Ass. Equine Pract., 655-656.

Dik K.J., Dyson S.J. and Vail T.B. (1995) Aseptic tenosynovitis of the digital flexor tendon sheath, fetlock and pastern annular ligament constriction. Vet. Clin. of North Am., Equine Pract. 11, 151-162.

Dik K.J., Van Den Belt A.J.M. and Keg P.R. (1991) Ultrasonographic evaluation of fetlock annular ligament constriction in the horse. Equine vet. J. 23, 285-288

Edinger H. (1996) Tendovaginoskopische und sonographische Befunde beim Ringbandsyndrom. Deutsche Veterinärmed. Gesellshaft Arbeitst., 253-257.

Fricker C. (1982) Zur Striktur des Fesselringbandes beim Pferd. Schweisz Arch. Tierheilk., 124, 315-319.

Genovese R.L., Rantanen N.W., Hauser M.L. and Simpson B.S. (1986) Diagnostic ultrasonography of equine limbs. Vet.Clin. of North Am.: Equine Pract., 2, 145-226.

Genovese R.L., Reef Virginia B., Longo Karen L., Byrd J.W. and Davis W.M. (1996) Superficial digital flexor tendonitis - Long term sonographic and clinical study of racehorses. Proc. 1st Dubai Int. Equine Symp., 187-205.

Gerring E.L. and Webbon P.M. (1984) Fetlock annular ligament desmotomy: a report of 24 cases. Equine vet. J. 16, 113-116.

Goodship A.E. and Birch H.L. (1996) The pathophisiology of the flexor tendons in the equine athlete. Proc. 1st Dubai Int. Equine Symp., 83-107.

Hago B.E.D. and Vaughan L.C. (1986) Radiographic anatomy of tendon sheaths and bursae in the horse. Equine vet. J., 18, 102-106.

Hogan P.A. and Bramlage L.R. (1995) Transection of the accessory ligament of the superficial digital flexor tendon for treatment of tendinitis: long term results in 61 Standardbred racehorses (1985-1992). Equine vet. J., 27, 221-226.

Mcllwraith C.W. (1987) Diseases of joints, tendons, ligaments and related structures. In: Stashak T.S., Ed: Adams' lameness in horses.Philadelphia, 339-485.

Nixon A.J. (1990) Endoscopy of the digital flexor tendon sheath in horses. Vet. Surg. 19, 266-271. 
Nixon A.J., Sams A.E. and Ducharme N.G. (1993) Endoscopically assisted annular ligament release in horses. Vet. Surg. 22, 501-507.

Nixon A.J. (1996) Tenosynovitis: diagnosis, treatment and prognosis. Proc. Dubai Int. Equine Symposium. 329-336.

Redding W.R. (1994) Evaluation of the equine digital flexor tendon sheath using diagnostic ultrasound and contrast radiography. Vet. Radiol. and Ultrasound 35, 42-48.

Schneider R.K., Bramlage L.R., Moore R.M., Mecklenburg L.M., Kohn C.W. and Gabel A.A. (1992) A retrospective study of 192 horses affected with septic arthritis/tenosynovitis. Equine vet. J. 24, 436-442.

Spaulding K. (1984) Ultrasonic anatomy of the tendons and ligaments in the distal metacarpal-metatarsal region of equine limb. Vet. Radiol., 25, 155-166.

Stanek C. and Edinger H. (1990) Röntgendiagnostik bei der Striktur des Fesselringbandes bzw. durch das Fesselringband beim Pferd. Pferdeheilkunde 6, 125-128.

Stashak T.S., Vail T.B., Park R.B. and Powers B.E. (1996) Fetlock annular ligament syndrome: results of desmotomy and factors that affect outcome in 49 horses. Proc. 5th ECVS Ann. Meeting, 72 (Abstr.).

Torre F., Dora Genocchi E. and Potschka R. (1991) La desmotomia del legamento anulare del nodello nel cavallo: 21 casi. Atti $X$ Congresso SIDI, 165-171.
Van den Berg M.J., Rijkenhuizen A.B.M., Németh F. and Gruys E. (1995) The fetlock tunnel syndrome: a macroscopic and microscopic study. The Vet. Quart., 17, 138-142.

Verschooten F. and Picavet T.M. (1986) Desmitis of the fetlock annular ligament in the horse. Equine vet. J. 18, 138-142.

Wright I.M. and Scott Manda (1989) Management of penetrating wounds in joints, tendon sheats and bursae. Equine vet. Educ. 1 , $15-22$.

\section{Acknowledgments}

The autors thank Roger K. Smith, from the Royal College of London, which pre-reviewed the original manuscript.

Dr. Fabio Torre

Clinica Equina Bagnarola

Via Armiggia, 25

I-40050 BAGNAROLA DI BUDRIO BO

Fax : 0039516922098

Frühjahrstreffen in Sevilla

\section{Orthopädische Erkrankungen der distalen Gliedmaße des Pferdes \\ - Aktuelle Diagnostik und Therapie - Konventionelle und minimalinvasive chirurgische Verfahren}

Rehe, Podotrochlose, Erkrankungen der Zehengelenke, Gleichbeinentzündung, Ringbandstriktur, Verletzungen von Sehnen und Sehnenscheiden, Frakturen der distalen Gliedmaße, Fehlstellungen

\section{Vorträge, OP-Demonstrationen, Workshop}

\section{Prof. Astrid Rijkenhuizen, Utrecht - Prof. Roy Gottschalk, Pretoria}

Centro Veterinario Itálica - Hospital Equino de Sevilla

\section{4.-28. März 1999}

Seminarsprache: Englisch

Tagungsgebühr: 1.200 DM (100.000 Pts.)

Vorprogramm:

Besichtigung von Sevilla und Tagesausflüge nach Granada und Cordoba

Information und Anmeldung:

Centro Veterinario Itálica, E 41970 Santiponce-Sevilla

Tel: 0034955997587 